\title{
THE INSTITUTE OF PHYSICS AND THE PHYSICAL SOCIETY
}

$\mathrm{T}$ THE report of the Council of the Institute of Physics and the Physical Society for the year 1961 was adopted at the annual general meeting of the Institute and Society held on July 10, 1962. During the year the Council met five times. It has been decided to mark annually the anniversary of the amalgamation of the Institute and Society in May 1960 by a series of meetings and functions, and the first of these was held on May 2 and $3,1961$. Sir John Cockcroft delivered his presidential address entitled "The Development of Physics" (Bull. Inst. Phys., 12, 109; May 1961) in the Royal Commonwealth Society's hall; the first annual dinner of the amalgamated body was held at the Park Lane Hotel, London; and the first annual representative meeting, consisting of the officers of the various branches and groups and past-presidents of the Institute and Society, was held at the headquarters of the Institute and Society, 47 Belgrave Square, London.

During the year under review 1,161 applications for election or transfer to the various grades of membership were received. The total membership on December 31,1961 , numbered 9,120 , consisting of 1,268 Fellows, 3,054 associates and 1,997 graduates, in addition to Fellows of the Physical Society, students and subscribers. This represents an increase of 400 over the year. The two technical colleges which applied for recognition for the purpose of the membership regulations relating to approved courses were visited by members of the Membership and Education Committee and both were accepted. Fifty-four technical colleges presented 987 candidates for the Ordinary National and thirty-five colleges 455 candidates for the Higher National Certificate in applied physics. Of the larger number, 239, of candidates for the graduateship examination, 64 were successful; fifteen question papers were set. An examination for Part 1 under the new regulations was also held; only three of the twenty-three candidates who entered were successful.

The Institute and Society was one of the sponsoring societies of the international conference held in the University of Manchester during September 4-8 to mark the jubilee of the discovery of the nucleus by Lord Rutherford. Other conferences and symposia were arranged during 1961.

The report of the committee under the chairmanship of Prof. R. V. Jones on problems facing university physics departments was submitted to the Robbins Committee, and has since received wide publication. All three of the Institute and Society's monthly periodicals, the Proceedings of the Physical Society, the British Journal of Applied Physics and the Journal of Scientific Instruments, increased in size compared with the previous year. A table in the annual report gives details of the material published in the periodicals during 1960 and 1961. Other publications sponsored by the Institute and Society were Noise in Electronic Devices and Selected Papers on Stress Analysis consisting of papers presented at Group conferences. Two new books, Automatic Control by A. E. De Barr and Viscosity and its Measurement by A. Dinsdale and F. Moore, are to be published in the "Monographs for Students" series, together with a new edition of J. Topping's Errors of Observation and their Measurement. A sixth volume in the series of "Laboratory and Workshop Notes", consisting of selections from the Journal of Scientific Instruments and compiled and edited by Dr. Ruth Lang, is shortly to appear.

The Institute and Society maintains ten specialist groups and nine branches in Great Britain, and two branches overseas, in Australia and Malaya respectively. A summary of the activities of these sections is given in the annual report, together with a list of the Council's representatives and nominees on joint and other committees and organizations.

The Australian branch consists of six divisions, and divisional activities have included a conference in Brisbane entitled "Sun-Earth Environment" organized by the Queensland and New South Wales Divisions at which more than forty papers were discussed by 120 delegates, in addition to about fifty scientific meetings and social events.

The activities of the Malayan branch were confined to its members attending colloquia in the Physics Department of the University of Malaya. The largest of the branches, the London and Home Counties Branch, with 4,113 members, held a symposium on "The Soil" during March in conjunction with the Royal Institute of Chemistry and the Institute of Biology. The subject of the Easter conference of the Education Group was "Communication: Physics for the Non-Specialist", and the summer meeting consisted of a visit to the research laboratories and new factory of Hilger and Watts, Ltd. During February the Electronics Group joined with the British Institution of Radio Engineers in promoting a meeting on "Tunnel Diodes". In the autumn a conference was held in Leamington on "The Physics of Gas Discharge Devices". The Low Temperature Group held a number of whole-day and half-day meetings. Topics discussed included: ultrasonic absorption and attenuation in metals at low temperatures; problems in thermal insulation; the generation of high d.-c. magnetic fields; superconductivity; ferromagnetism and antiferromagnetism at low temperatures; and the thermodynamic properties of fluid helium. The Simon Memorial Prize was awarded to Dr. I. M. Lifschitz of the Academy of Sciences of the Ukrainian S.S.R., Kharkov.

On the recommendation of its Awards Committee the Council approved some changes in the arrangements concerning the various awards (lectureships, medals and prizes). It authorized a new award, to be called the Maxwell Medal and Prize, for outstanding contributions to theoretical physics carried out within ten years of the award. The recipients of the Duddell Medal, C. V. Boys Prize, and Charles Chree Medal and Prize, were Dr. J. B. Adams, Prof. A. W. Merrison and Dr. Scott E. Forbush, respectively. The text of the C.V. Boys Lecture, entitled "Counter Techniques in High Energy Nuclear Physics: Rare Decays of pi and mu-mesons", has been published (Proc. Phys. Soc., 78, 1116; Dec. 1961). The Guthrie Lecture was delivered by Dr. D. Shoenberg on the subject of the de Haas-van Alphen effect and the electronic structure of metals (Proc. Phys. Soc., 79, 1; Jan. 1962), and 
the Thomas Young Oration on the application of frequency response techniques in optics by Dr. H. H. Hopkins. The Holweck Medal and Prize was presented by the French Physical Society to Prof. A. B. Pipperd in Paris on May 12.

The total response to the Physics Trust Fund Appeal at the end of the year under review was $£ 117,146$.
The cost of the educational and scientific work of the Institute and Society now runs at about $£ 25,000$ a year, reflecting the substantial planned increase to meet which the Trust Fund Appeal was mainly established. The accounts included in the annual report cover the first full year's working of the amalgamated Institute and Society.
S. WeINTROUB

\section{NUCLEAR RESEARCH IN FRANCE}

$\mathrm{T}$ HE Nuclear Research Centre of Fontenay-AuxRoses is affiliated to the Commisariat a l'Energie Atomique and employs a staff of 1,000 (the total staff of the Commissariat is 14,000 persons) (French Science News, No. 2, April-June 1962). The Centre comprises the following departments:

\section{(1) Atomic Reactors}

(a) Reactor protection studies made with reactors Zoë and Triton. Zö is a moderated, heavy-water coolod, natural uranium reactor which produces a maximum thermal neutron flux of $10^{12}$ neutrons $/ \mathrm{cm}^{2} /$ sec. It was the first reactor built in France. Triton is a double-core, 20 per cent onriched uranium, watermoderated swimming-pool reactor, cooled by forced water-circulation. It develops a power of $150 \mathrm{~kW}$ and has a flux of $10^{13}$ neutrons $/ \mathrm{cm}^{2} / \mathrm{sec}$.

A $600-\mathrm{keV}$ Sames accelerator is also available in the Department and is used for the measurement of monoenergetic neutron propagation and diffusion in matter.

(b) Critical experiments. Sections of various materials are measured in a reactor by the oscillation method: Zoë and Minerve are used for this purpose. The latter is a low-power (100 W) experimental reactor, which produces maximum thermal flux of $5 \times 10^{9}$ noutrons $/ \mathrm{cm}^{2} / \mathrm{sec}$. It is also used for measuring neutron absorption in samples of the materials used for the construction of reactors, and for neutron studies on lattices moderated with light water.

(c) Liquid metals. This section carries out research on the use of cortain metals in the molten state as coolants in atomic reactors. The main application is the cooling of fast neutron reactors by means of sodium, sodium-potassium alloy, lead, lead-bismuth eutectic or mercury. The results of this research are to be applied to the cooling of Rapsodie, which is to be built at the Nuclear Centre at Cadarache.

\section{(2) Controlled Fusion}

(a) Research on controlled fusion, carried out by a joint Commissariat-Euratom research group. Resoarch covers three main subjects: the 'striction' programme, where induced discharges, carrying $150,000 \mathrm{amp}$, are studied; the 'continuous mirror' programme, which uses accelorated ion injections; and the 'pulsed mirror' programme, which uses an apparatus for studying adiabatic compression.

(b) Theory of ionized gases. This section carries out the theoretical work required for controlled fusion research.

\section{(3) Chemistry}

(a) Investigations, research and chemical applications. The laboratories are equipped for the study and dovelopment of: the chemical processing of uranium, thorium and beryllium ore; the purification of 0.890 per cent enriched uranium; the purification of elements such as beryllium and zirconium; the processing of chemical plant waste.

(b) Analytical studies. This section carries out analytical studies which are new or which are better adapted to atomic energy problems, and the initial development of special equipment such as automatic analysers.

(c) Contracts. Work here consists mainly of the technical checking of contracts between the Cornmissariat and other organizations.

\section{(4) Plutonium}

This department has a series of 'hot' laboratories for the handling and study of radioactive materials.

(a) Plutonium chemistry. Here processes whereby the constituents of an irradiated fuel are separated and recuperated in pure forms aro studied. Work follows three main lines: improvement of the solvent process; influence of progress made in fuels and cladding; dry processes.

Plutonium base ceramic and transuranium elements are also investigated.

(b) Plutonium metallurgy. The initial research on plutonium alloys was to examine aluminium base alloys. A plutonium technology workshop was built and metal transformation techniques were adapted to radioactive materials.

\section{(5) Mineralogy}

Analytical work is carried out as well as applied research work on radiogeology.

\section{(6) Mines and Mining Research}

The main department is at Fontenay; but its activities cover the whole of France, former French territories in Africa, and Madagascar.

\section{(7) Biology Department}

(a) Atomic hygiene and radiopathology. The fundamental problems of radiological protection are studied. In atomic hygiene, the aim is to set the security-level of irradiation and radioactive contamination.

Work on radioactive contamination deals with problems of industrial hygiene concerning the possible formation of liquid or solid radioactive aerosols in laboratories or workshops, and with problems of contamination via the digestive tract or via the skin.

Two laboratories carry out analyses which show any slight contamination, whether normal or accidental, of persons or of the biological environment.

(b) Radiation check and radioactive engineering. Activities are as follows: operation of the photometry and micrometry laboratories for checking the degree of irradiation by photographic or nuclear emulsions; supervision of the radioactivity of nuclear installation surroundings; the regular radiochemical analysis of rain and run-off; the study of natural radioactivity mainly by radon and thoron assay. 